\title{
Which is better for humans, animal milk or vegetable milk?
}

\section{Editorial}

Animal milk is a fluid lacteal secretion obtained by the female of all mammals. Milk has an important function because it is a source of the essential nutrients for the proper development and maintenance of the human body. It must supply amino acids, vitamins, and minerals. It is very beneficial to balance human diet. Because milk has good quality protein such as caseins and serum proteins, it also has good amount of calcium and vitamins, specially vitamin A, B and C, riboflavin, niacin and folic acid. Hence, milk is an ideal nutrient for both infants and adults. ${ }^{1}$ Moreover, milk contains bio-protective molecules which are afford health security to humans including antimicrobial substances such as immunoglobulin, lactoperoxidase and lactotransferrin and it also contains enzymes and enzyme inhibitors, vitamin-binding carrier proteins. ${ }^{2}$ Further it contains trace elements such as nickel, selenium, zinc and iron.

Above all of that, the fermentation of milk greatly increases the nutritional and healthy values. Fermented dairy foods have constituted a vital part of human diet in many regions of the world since times immemorial. They have been consumed ever since the domestication of animals. Evidence for the use of fermented milks comes from archeological findings associated with the Sumerians and Babylonians of Mesopotamia, the Pharoses of northeast Africa and the Indo-Aryans of the Indian subcontinent. It was reported that consuming fermented dairy products caused to longevity. ${ }^{3,4}$ Fermented milk products not only are consumed for their benefits but also for refreshing effects. Their popularity is said to be attributed to the effective use of consumer-driven flavors and milder cultures. ${ }^{5}$ These products already have a positive health image, ${ }^{6,7}$ which can be further enhanced by the addition of probiotic bacteria with therapeutic properties. Various microorganisms characterize the diversity of fermented milks around the world. Lactic fermentation by bacteria transforms milk into the majority of products. ${ }^{8}$ A combination of lactic starters and yeasts is used for some products, and in a few cases lactic fermentation combined with molds makes up the flora. In many countries, yogurt and fermented milks with probiotic cultures are available. These are made with defined cultures that have been scientifically documented to display certain health benefits. ${ }^{9}$ Fermented milks may be mixed with water to make a refreshing beverage. Salt, sugar, spices or fruits may be added to enhance taste. Liquid yogurt is the prime example. Spoonable yogurt has significant commercial importance all over the world. It is sold in cups and tubes.

However, dairy products still are the most typical carriers of probiotic bacteria, but lactose intolerance, cholesterol content, allergic potency of milk-proteins and also requiring of vegetarian aliment that are some inconveniences related to their consumption. Hence, there is an increasing demand for non-dairy probiotic products lacking the dairy allergens. ${ }^{10}$

During recent years, non-dairy milk types (vegetable milk), such as soymilk, coconut milk, almonds milk, rice milk, peanut milk and oat milk, have been an increased demand from consumers due to their

\author{
Volume 2 Issue 5 - 2015
}

\author{
Magdy Mohamed Ismail \\ Dairy Technology Department, Agricultural Research Center, \\ Egypt
}

Correspondence: Magdy Mohamed Ismail, Dairy Technology Department,Animal Production Research Institute, Agricultural Research Center, Egypt, Email magdy250@yahoo.com

Received:September 23, 2015 | Published: September 25, 2015

high functional properties. The cereal and grain milks also do not contain cholesterol or lactose; hence, these milk types are preferred by someone who are vegetarians, have special diet or who are lactose intolerant. ${ }^{11}$

Over the past two decades, research has shown strong evidence for the potential use of soy in the prevention of chronic diseases, which has positively affected soymilk and soy-foods consumption. ${ }^{12}$ Oat is a good source of many compounds that show antioxidant activity with their vitamins, phenolic acids, avenanthramides, flavonoids, sterols and phytic acid (David, 2000). Oat milk also contains high percentage of fiber, vitamins $\mathrm{A}, \mathrm{D}, \mathrm{E}$ and $\mathrm{B} 1$, minerals such as calcium, potassium, sodium, magnesium and iron. This composition of oat and oat milk provides more functionality to food such as improving beneficial effects for digestive system and preventing against colonorectal cancer and helping to maintain an optimal weight due to high fiber content. Also oat milk exhibits cholesterol and lipidlowering effects. ${ }^{13}$ Peanut milk is an inexpensive source of protein and calories for human consumption. It is seen as a low-cost substitute for dairy milk for the developing countries. Being free of cholesterol and lactose, peanut milk is also a suitable food for lactose-intolerant consumers, vegetarians and milk-allergy patients. Peanut milk is characterized as a source of high vegetable proteins, low in cholesterol, thus has attracted much attention from consumers. Because it is also extremely rich in minerals and essential fatty acids, such as linoleic and oleic, which are highly valuable in human nutrition. ${ }^{14}$ Rice seems to be nonallergenic and rice milk has been fed to infants allergic to cow's milk. Also, it is good for people who are lactose intolerant and those with soy or nuts allergies. Rice and its products are an important source of B vitamins. ${ }^{15}$ Coconut milk is rich in phosphorus; the milk supplies the body with nearly a quarter of daily value of iron thereby resulting in the prevention of anaemia. The milk helps to decrease the risk of joint inflammation due to its high selenium content. The health of prostate gland could be promoted due to the presence of zinc in coconut milk. ${ }^{16}$

General spiking, animal milk has advantages and disadvantages, also vegetable milk has advantages and disadvantages, so we should not replace one with the other, except in special cases limited. 


\section{Acknowledgements}

None.

\section{Conflict of interest}

Author declares that there is no conflict of interest.

\section{References}

1. Yetisemeyen A, Sezgin E, Atamer M, et al. Süt Teknolojisi. Ankara Üniversitesi Ziraat Fakültesi Süt Teknolojisi Bölümü Ankara. Yayın no: 1560.2007.

2. Fox PF, McSweeney PLH, Cogan TM, et al. Fundamentals of Cheese Science. Gaithersburg, Maryland: Aspen Publishers; 2000.

3. Tamime AY, Robinson RK. Yogurt Science and Technology. 3rd ed. Cambridge, England: Woodhead Publishing Limited, CRC Press; 2007.

4. Hui YH, Evranuz OE. Handbook of Animal-based Fermented Food and Beverage Technology. 2nd ed. Boca Raton, FL: CRC Press; 2012. p. 213-233.

5. Jensen RG, Kroger M. The importance of milk and milk products in the diet. In: Miller GD, Jarvis JK, editors. Handbook of Dairy Foods and Nutrition. 2nd ed. Boca Raton, USA, Florida. 2000. p. 51-52.

6. Jelen P, Gallmann P, Coolbear T. Current and future applications of fermentation technology in the dairy industry. IDF Seminar on Aroma and Texture of Fermented Milk. 2003:10-20.

7. Valli C, Traill WB. Culture and food: a model of yoghurt consumption in the EU. Food Qual Pref. 2005;16(4):291-304.
8. Salampessy J, Kailasapathy K. Fermented dairy ingredients. In: Chandan RC, Kilara A, editors. Dairy Ingredients for Food Processing. Ames, IA: Wiley-Blackwell; 2011. p. 335-356.

9. Chandan RC, Kilara A. Nutritive and health attributes of dairy ingredients. In: Chandan RC, Kilara A, editors. Dairy Ingredients for Food Processing. Ames, IA: Wiley-Blackwell; 2011. p. 387-419.

10. Alegre I, Vinas I, Usall J, et al. Microbiological and physicochemical quality of fresh-cut apple enriched with the probiotic strain Lactobacillus rhamnosus GG. Food Microbiol. 2011;28(1):59-66.

11. Durand A, Franks GV, Hosken RW. Particle Sizes and Stability of UHT Bovine, Cereal and Grain milks. Food Hydrocolloids. 2002;17(5):671-678.

12. Setchell KD. Soy Isoflavones-Benefits and Risks from Nature's Selective Estrogen Receptor Modulators (SERMs). J Am Coll Nutr. 2001;20(5 Suppl):354S-362S.

13. Kahraman C. Production of kefir from bovine and oat milk mixture. 2011.

14. Diarra K, Nong ZG, Jie C. Peanut milk and peanut milk based products production: a review. Crit Rev Food Sci Nutr. 2005;45(5):405-423.

15. Lalić J, Denić M, Sunarić S, et al. Assessment of thiamine content in some dairy products and rice milk. CyTA - Journal of Food. 2014;12(3):203-209.

16. Belewu MA, Belewu KY, Olatunji SA. Preparation, Compositional and Organoleptic Qualities. BioScience Research Bulletin. 2005;21(2):129-137. 